\title{
Preparation of novel magnetic polyurethane foam nanocomposites by using core-shell nanoparticles
}

\author{
Mir Mohammad Alavi Nikje ${ }^{1 *}$, Sahebeh Tamaddoni Moghaddam ${ }^{1}$ and Maede Noruzian ${ }^{1}$
}

'Department of Chemistry, Faculty of Science, Imam Khomeini International University, Qazvin, Iran

*drmm.alavi@gmail.com

\begin{abstract}
Iron oxide magnetic nanoparticles (NP's) converted to the core- shell structres by reacting with by n-(2-aminoethyl)-3aminopropyl trimethoxysilane (AEAP) incorporated in polyurethane flexible (PUF) foam formulations. Fourier transform spectra, thermal gravimetric analysis, scanning electron images, thermo-mechanical analysis and magnetic properties of the prepared nanocomposites were studied. Obtained data shown that by the increasing of the amine modified magnetic iron oxide NP's up to 3\% in the polymer matrix, thermal and magnetic properties improved in comparison with pristine foams. In addition, due to the presence of functional groups on the magnetic NP's surface, hard phases formation decrease in the bulk polymer and cause decreasing of glass transition temperature.
\end{abstract}

Keywords: magnetic iron oxide, magnetic nanoparticles, $N$-(2-aminoethyl)-3-aminopropyl trimethoxysilane (AEAP), Polyurethane flexible (PUF) foam.

\section{Introduction}

Polyurethane's (PU's) as a well-known class of versatile polymeric materials prepare by a simple condensation reactions and because of their unique properties have been used in various applications namely, adhesives, coatings, elastomers and foams ${ }^{[1,2]}$. In the foam categories, flexible families are the largest product family by quantity by having more than $40 \%$ of all PU foams production capacity. Flexible PU foam because of its lightness and strength is used as cushioning namely, car seats, mattresses and packaging, but having their main own merits and drawbacks ${ }^{[3,4]}$. The main drawbacks referee to the low load bearing properties and low thermal stabilities in comparing to the other polymeric materials. In order to overcoming these drawbacks, in the recent years some novel nanocomposites are prepared ${ }^{[5]}$. Nanocomposites display prior properties when compared with their microcomposites counterparts, due to the much stronger interactions between the dispersed nanoparticles (NP's) domains and the polymer matrix ${ }^{[6]}$. In this case and in flexible PU foams, the incorporation of nanoparticles increase foam density as well as improve compression and tear properties ${ }^{[7]}$. Literature survey reveals the application of well-known NPs in the flexible foam formulations namely, fumed silica ${ }^{[8]}$, calcium carbonate ${ }^{[7]}$, nanofibers ${ }^{[9]}$, carbon nanotubes ${ }^{[9,10]}$, zinc borate, phosphorous and expandable graphite ${ }^{[11]}$ in order to improving of thermal, mechanical, acoustic and flame retardancy properties, respectively because of the high performances of nanoparticles in improving of target properties ${ }^{[12]}$. Above all, the roles of inorganic such as magnetic iron oxide NP's (MNP's) by having unique and high performances are undeniable. For example, application of MNP's in the polymer matrix leads to the improvements in the thermal and magnetic properties and open new windows for the preparation of the new magnetic materials namely, magnetic polyurethane foams ${ }^{[13]}$. Among all of merits, the surface energy of MNP's is very high and tends to agglomerate and is very difficult dispersed uniformly in to the polymer matrix ${ }^{[14]}$. Surface modification of MNP's is used to improve the performance of nanoparticles and create

a good linkage between inorganic filler and organic polymer matrices ${ }^{[15]}$. In this cage, coupling agents has been used for modification of magnetic iron oxide via non-magnetic shell formation of silica what can reduce the agglomerating, enhances thermal resistance of iron oxide nanoparticles and improve the compatibility between magnetic $\mathrm{Fe}_{3} \mathrm{O}_{4}$ NP's and PU matrices ${ }^{[16,17]}$.

Magnetic nanoparticles incorporated in to the polymer matrix by some methods, such as melting, solution and insitu polymerization which the later is the most common and well known method. The in-situ polymerization of MNP's in the polymer matrix is an excellent method to control the mean size and size dispersion of a nanoparticle population, which are crucial factor in determination the properties of the nanocomposites ${ }^{[18]}$. In our previous work, magnetic polyurethane rigid foam nanocomposite were prepared by incorporation of $\mathrm{Fe}_{3} \mathrm{O}_{4} @ \mathrm{SiO}_{2}$ NP's in polymer matrix. The results indicate the performance of MNP's in enhancing of the thermal resistances, storage modulus, and magnetic properties of filled rigid foam in comparison with pure $\mathrm{PU}^{[5]}$.

In this study, the super paramagnetic $\mathrm{Fe}_{3} \mathrm{O}_{4} @ \mathrm{AEAP}$ NP's incorporated in to the PU flexible foam. In order to improve the dispersion of $\mathrm{Fe}_{3} \mathrm{O}_{4}$ NP's in PU matrix and compatibility between $\mathrm{Fe}_{3} \mathrm{O}_{4} \mathrm{NP}$ 's and $\mathrm{PU}$ matrix, NP's were modified with AEAP and $\mathrm{Fe}_{3} \mathrm{O}_{4} @$ AEAP-PU flexible foam nanocomposites were prepared via in-situ polymerization. Our data showed superior and significant thermal stability and magnetic properties of resultant foams when MNP's incorporated up to $3.0 \%$.

\section{Experimental}

\subsection{Materials}

Daltoflex EC ${ }^{\circledast} 20240$ formulated virgin polyol. The polyol (propylene oxide-ethylene oxide copolyether) as a colorless viscous liquid, having viscosity $1.250 \mathrm{~Pa}$ s at $208^{\circ} \mathrm{C}$, specific gravity $1.035 \mathrm{~g} / \mathrm{cm}^{3}$ at $208^{\circ} \mathrm{C}$, fire point $240{ }^{\circ} \mathrm{C}$, Mw 1900 , 
functionality 2 and hydroxyl numbers $59 \mathrm{mg} \mathrm{KOH} / \mathrm{g}$. Isocyanate was Suprasec 2027 diphenylmethanediisocyanate (MDI)-based prepolymer (dark brown liquid, having viscosity $0.220 \mathrm{~Pa}$ s at $258^{\circ} \mathrm{C}$, specific gravity $1.23 \mathrm{~g} / \mathrm{cm}^{3}$ at $258{ }^{\circ} \mathrm{C}, \mathrm{NCO}$ value $30.9 \%$ by weight of $\mathrm{NCO}$ groups analysis (group weight: $42 \mathrm{~g} / \mathrm{mol}$ ), average functionality 2.7 , flash point $233{ }^{\circ} \mathrm{C}$, and fire point $2458 \mathrm{C}$ ). Daltoflex EC 20240 and Suprasec ${ }^{\circledR} 2027$ are chlorofluorocarbon (CFC) free systems, purchased from Huntsman Company with starting formulation as Daltoflex EC 20240: 100 pbw and Suprasec 2027: 65 pbw.

The following reagents were purchased from Merck and used as received without further purification: Iron (II) chloride tetrahydrate $\left(\mathrm{FeCl}_{2} \cdot 4 \mathrm{H}_{2} \mathrm{O}, 99.7 \%\right)$, iron (III) chloride hexahydrate $\left(\mathrm{FeCl}_{3} \cdot 6 \mathrm{H}_{2} \mathrm{O}, 99.0 \%\right)$, ammonia $\left(\mathrm{NH}_{3} \cdot \mathrm{H}_{2} \mathrm{O}, 25 \%-28 \%\right)$, ethanol ( $\left.\mathrm{C}_{2} \mathrm{H}_{5} \mathrm{OH} 99.7 \%\right)$, n-(2-aminoethyl)-3-aminopropyl trimethoxysilane (AEAP) and citric acid.

\subsection{Instruments}

Morphology studies and particle size of magnetic nanoparticles $\left(\mathrm{Fe}_{3} \mathrm{O}_{4}\right)$ were done on a field emission scanning electron microscopy (Hitachi model Se 4160). Fourier transform infrared spectroscopy (FT-IR) spectra were done on a Bruker Tensor 27 spectrophotometer. The thermogravimetric analysis (TGA) of $\mathrm{Fe}_{3} \mathrm{O}_{4}$ and $\mathrm{Fe}_{3} \mathrm{O}_{4} @$ AEAP NP's and magnetic nanocomposite were performed on a Perkin-Elmer Paris Diamond TG/DTG under $\mathrm{N}_{2}$ and $\mathrm{O}_{2}$ atmosphere at a heating rate of $10^{\circ} \mathrm{C} / \mathrm{min}$. Thermal mechanical analysis (TMA) was carried out by using a Linseis TMA instrument (TP 1000, Germany) over a temperature range from -100 to $250^{\circ} \mathrm{C}$ and in compression mode. Magnetic hysteresis loops of magnetic foams were measured via a vibration sample magnetometer (VSM). To disperse modified magnetic nanoparticles in the polymer matrix, an ultrasonic homogenizer (Hielscher, Up 200S, Germany) was used.

\subsection{Synthesis of $\mathrm{Fe}_{3} \mathrm{O}_{4} @ A E A P$ nanoparticles}

The magnetic NP's were prepared through a co-precipitation method by the reaction of ferric and ferrous $(2 / 1 \mathrm{in} \mathrm{mol} / \mathrm{mol})$ in ammonia solution as reported by elsewhere ${ }^{[5]} \cdot \mathrm{Fe}_{3} \mathrm{O}_{4} @$ AEAP NP's was synthesized in two steps which in the first step, magnetic NP's (100mg) was dispersed in ethanol/water $(5 / 1)(110 \mathrm{ml})$ and sonicated for $20 \mathrm{~min}$ by drop wise addition of acetic acid and adjusting of $\mathrm{pH}$ at 4 . Then $\operatorname{AEAP}(0.3 \mathrm{ml})$ was added to the solution and the mixture was stirred mechanically at room temperature for an additional $2 \mathrm{~h}$. Finally, the core-shell NP was separated and washed with distilled water $(2 \times 100 \mathrm{ml})$, collected and dried at $50{ }^{\circ} \mathrm{C}$ in an oven overnight and characterized.

\subsection{Synthesis of polymer}

\subsubsection{Foam processing}

When the isocyanate is mixed with the polyol, the exothermic chemical reactions start. The foam processing is followed by the cream time, gel time, rise time and tack-free time ${ }^{[15]}$. The cream time is the first step and corresponds to the start of bubble rise and the time at which the clear mixture turns creamy and starts to expand. Gel time is the first point of stable network formation by intensive allophanate cross-links as well as urethane. Rise time is the time between the start of the final mixing and the time of complete expansion of the foaming mass. At the tack-free time, the outer surface of the foam losses its adhesiveness and the foam can be removed from the mold.

\subsubsection{Synthesis of $\mathrm{Fe}_{3} \mathrm{O}_{4} @ A E A P-P U$ flexible foam nanocomposite}

In the first step, modified MNP was dispersed in the polyol matrix in weight percents of $0.5,1.0,1.5,2.0,2.5$, and 3.0 by vigorous stirring for $3 \mathrm{~min}$ and the pre-mixture was sonicated for $4 \mathrm{~min}$ via an ultrasonic probe to the formation of a homogeneous mixture. In the next step, nano -particulated polyol was hand mixed with MDI in a $250 \mathrm{ml}$ paper cup at 10:6 (polyol/MDI) weight ratios. Finally the sample was kept at room temperature for $24 \mathrm{~h}$ for complete post curing and further testing ${ }^{[5]}$. The reaction pathway of PU-flexible foam nanocomposite formation is shown in Scheme 1. As shown in scheme, by incorporation of AEAP modified magnetic nanoparticles in polyurethane matrix, the interaction between isocyanate group and amino-group with formation of urea fragments have been created.

\section{Result and Discussion}

\subsection{Characterizations of magnetic and $\mathrm{Fe}_{3} \mathrm{O}_{4} @ A E A P$ nanoparticles (FT-IR, TGA and SEM analysis)}

The AEAP coating on the $\mathrm{Fe}_{3} \mathrm{O}_{4}$ NP's was confirmed by FT-IR spectroscopy (Figure 1). The stretching vibration frequencies at 480 and $582 \mathrm{Cm}^{-1}$ are attributed to the $\mathrm{Fe}-\mathrm{O}$ functional groups of magnetic nanoparticles. After the coating of AEAP to $\mathrm{Fe}_{3} \mathrm{O}_{4}$ NP's, the Fe-O-Si band stretching vibration appeared at $584 \mathrm{Cm}^{-1}$ and overlaps with $\mathrm{Fe}-\mathrm{O}$ bands ${ }^{[19]}$. In addition, the bands at $1091 \mathrm{Cm}^{-1}$ corresponded to the stretching vibration of the Si-O bond. The absorption band at $3479 \mathrm{Cm}^{-1}$ in the spectrum of the $\mathrm{Fe}_{3} \mathrm{O}_{4} @$ AEAP NP is attributed to the -NH group introduced from the AEAP. Furthermore, the presence of band at 2896 and $2972 \mathrm{Cm}^{-1}$ are corresponded to the stretching vibration of $\mathrm{C}-\mathrm{H}$ groups on $\mathrm{AEAP}^{[6,20]}$. The obtained results from FTIR studies resulted that the surface of the $\mathrm{Fe}_{3} \mathrm{O}_{4}$ NP's was successfully modified with AEAP.

Another method for confirmation of surface modification is thermo-gravimetric analysis method. Figure 2 shows the TGA of pure MNP's $\left(\mathrm{Fe}_{3} \mathrm{O}_{4}\right)$ and $\mathrm{Fe}_{3} \mathrm{O}_{4} @$ AEAP NP's. The weight loss of pure MNP's take place below $120^{\circ} \mathrm{C}$ and calculated as $5 \%$ which attributed to the evaporation of water molecules ${ }^{[21]}$. In addition, at $700{ }^{\circ} \mathrm{C}$ the total weight losses of $\mathrm{Fe}_{3} \mathrm{O}_{4} @$ AEAP NP are assigned as 22\%. Taking in to account the weight loss of pure MNP's, it could be expected that the content of AEAP moiety on the magnetic NP's surface was about $17 \%$.

For morphology studies of $\mathrm{Fe}_{3} \mathrm{O}_{4} @$ AEAP NP, SEM images has been used and data shown in Figure 3. It can be observed from the images that magnetic and $\mathrm{Fe}_{3} \mathrm{O}_{4} @$ AEAP particulates have uniform spherical shapes with the size in the range of 30-40 $\mathrm{nm}$ and 50-60 nm, respectively. 


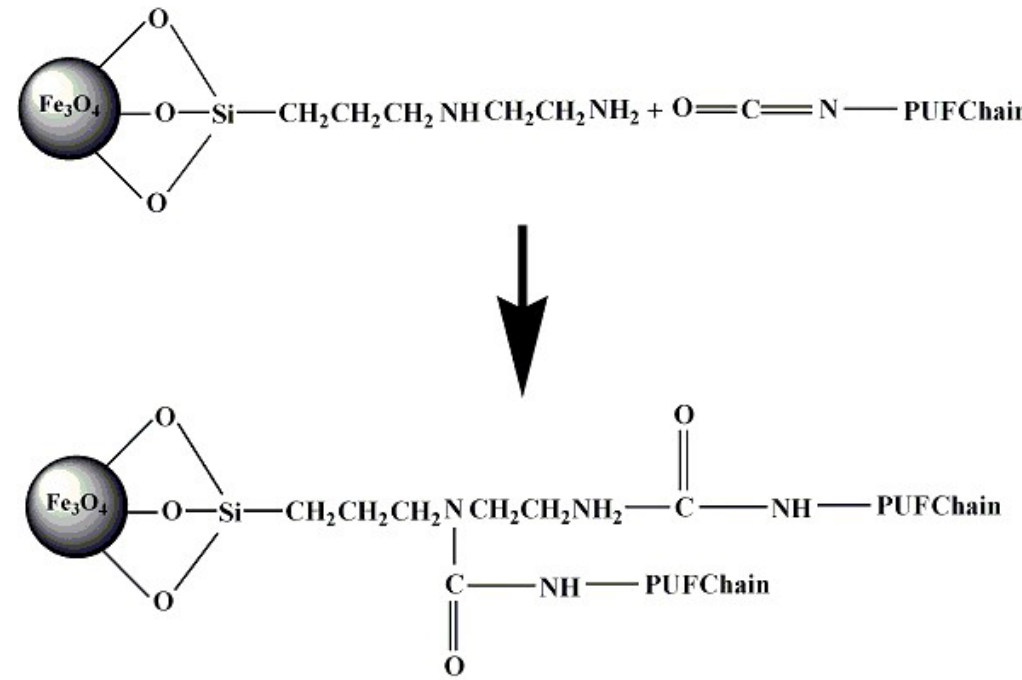

Scheme 1. The formation of PU flexible foam nanocomposites.

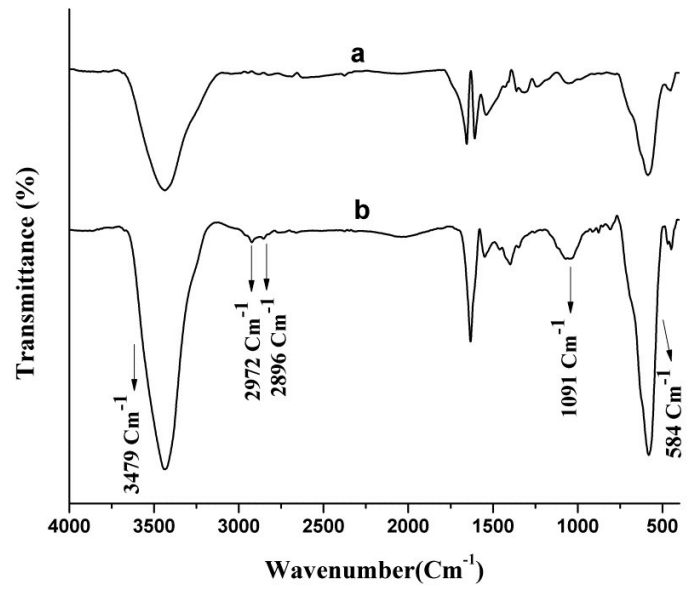

Figure 1. FT-IR spectra of (a) $\mathrm{Fe}_{3} \mathrm{O}_{4}$ and (b) $\mathrm{Fe}_{3} \mathrm{O}_{4}$ (aEAP nanoparticles.

\subsection{Characterization of PU-flexible foams nanocomposite}

\subsubsection{FT-IR analysis}

The ATR spectra of $\mathrm{Fe}_{3} \mathrm{O}_{4} @$ AEAP/PUF nanocomposite containing $\mathrm{Fe}_{3} \mathrm{O}_{4} @$ AEAP NP's (1.5 to 3.0\%) are shown in the Figure 4. As shown in the spectra, the absorption at $1105 \mathrm{Cm}^{-1}$ is related to $-\mathrm{C}-\mathrm{O}$ functional group. Similarly, band at $1234 \mathrm{Cm}^{-1}$ corresponded to the $\mathrm{C}-\mathrm{N}$ functional groups $(\mathrm{FG})$ of the urethane. Furthermore, it can be seen that all PU samples have similar vibration bond at $3348 \mathrm{Cm}^{-1}$ (hydrogen-bonded stretching vibration of urethane groups), $1595 \mathrm{Cm}^{-1}$ (N-H bending vibrations), and $1714 \mathrm{Cm}^{-1}(\mathrm{C}=\mathrm{O})$ what are corresponded to the urethane functional groups. In the meantime and as shown in figure, the $-\mathrm{NCO}$ groups appeared at $2293 \mathrm{Cm}^{-1}$ and indicated that the isocyanate

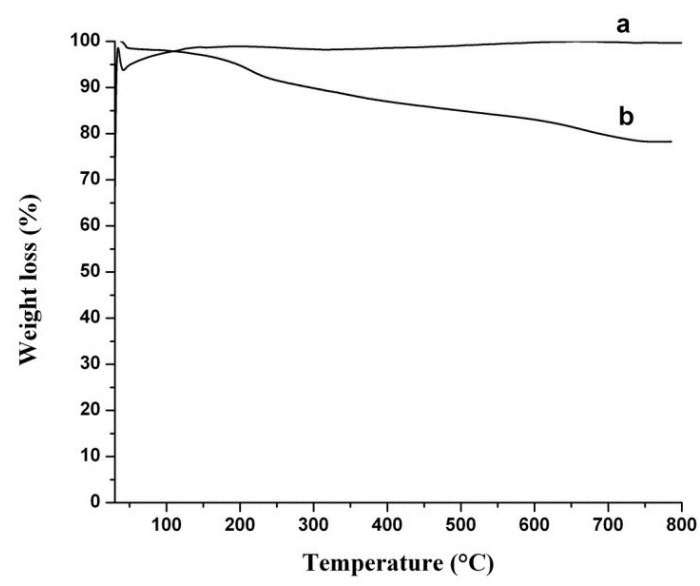

Figure 2. TGA curves for (a) $\mathrm{Fe}_{3} \mathrm{O}_{4}$ and (b) $\mathrm{Fe}_{3} \mathrm{O}_{4}$ @AEAP nanoparticles.

groups have not completely reacted ${ }^{[22]}$. Finally, the bands at 2889 and $2976 \mathrm{Cm}^{-1}$ are assigned to the asymmetrical C-H stretching and symmetrical stretching of polyether groups in the aliphatic chains, respectively ${ }^{[23,24]}$.

\subsubsection{Morphology studies (SEM)}

Surface morphological analysis of the magnetic nanocomposite was done by scanning electron microscopy (SEM) and shown in Figure 5 and cell density $\left(\mathrm{N}_{\mathrm{f}}\right)$ is calculated by using Equation $1^{[12]}$. In this equation, $\mathrm{n}$ is the number of cells, A the area of the micrograph in $\mathrm{Cm}^{2}$, and $\mathrm{M}$ is the magnification factor. As shown in the Table 1, by increasing of modified MNP's from 1.5 to $3 \%$, cell density was increased and cell size was reduced. These results indicate that the nature of the dispersion plays a fundamental role in controlling the cell size during foaming. 

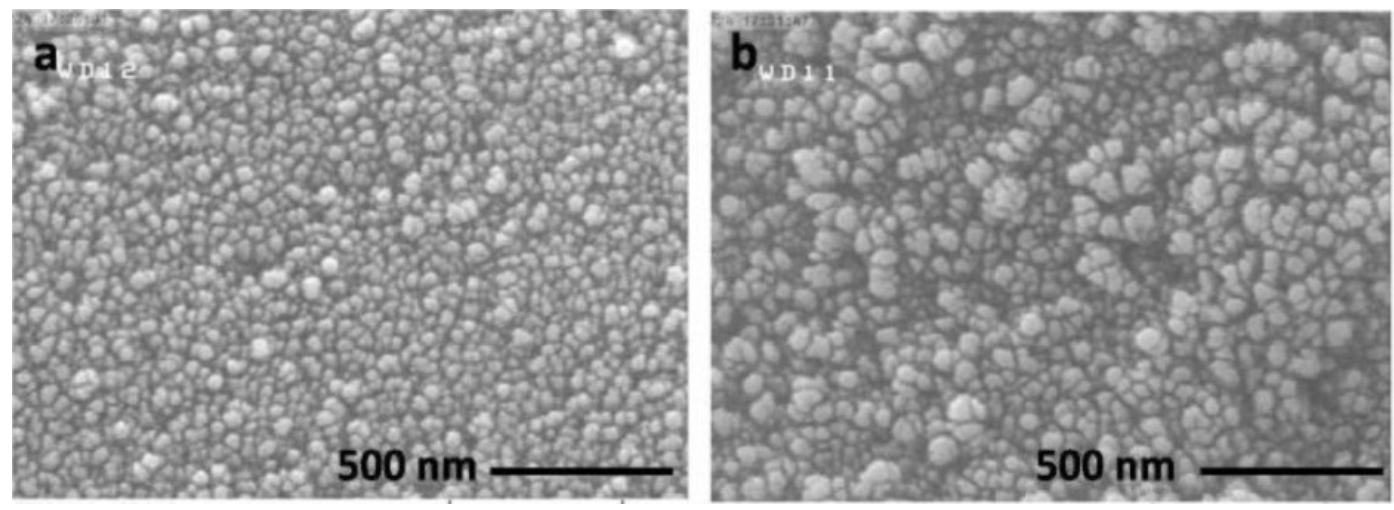

Figure 3. FE-SEM images of synthesized (a) $\mathrm{Fe}_{3} \mathrm{O}_{4}$ and (b) $\mathrm{Fe}_{3} \mathrm{O}_{4} @ A E A P$ nanoparticles.

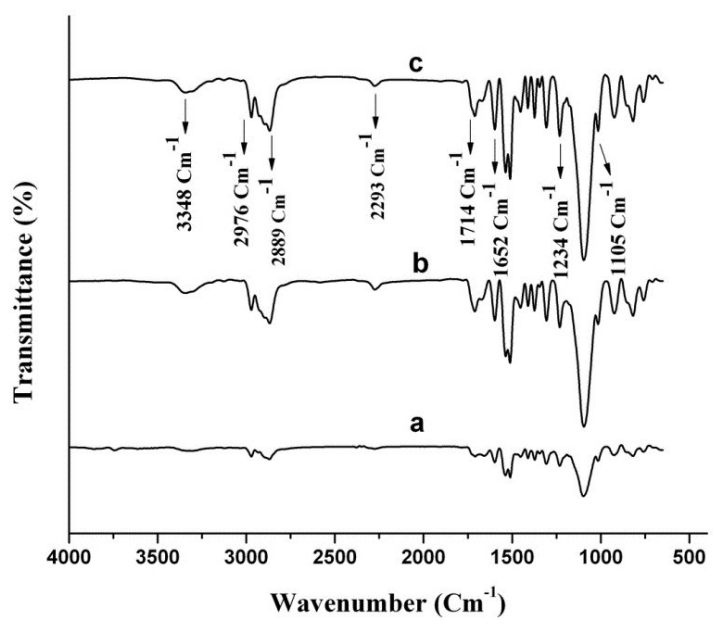

Figure 4. IR-ATR spectra of $\mathrm{Fe}_{3} \mathrm{O}_{4} @ A E A P-P U F$ foams, with different content of $\mathrm{Fe}_{3} \mathrm{O}_{4} @$ aEAP: (a) 0; (b) 1.5 and (c) 3.0\%.

Table 1. Cell densities of PUF foams.

\begin{tabular}{cccc}
\hline NP's (\%) & $\mathbf{a}(\mathbf{0 . 0})$ & $\mathbf{b}(\mathbf{1 . 5})$ & $\mathbf{c}(\mathbf{3 . 0 )}$ \\
\hline $\mathbf{N}_{\mathrm{f}}\left(\mathbf{C e l l s} / \mathbf{C m}^{3}\right) \times \mathbf{1 0}^{5}$ & 0.198 & 0.298 & 0.364 \\
\hline
\end{tabular}

$$
N_{f}=\left(\frac{n M^{2}}{A}\right)^{\frac{3}{2}}
$$

In addition, the foam density (D) is calculated using the Equation 2:

$$
D=\frac{M}{V}
$$

In this equation, $\mathrm{M}$ is mass (gr) and $\mathrm{V}$ is the volume $\left(\mathrm{Cm}^{3}\right)$ of the foam, respectively. As shown in Table 2, by increasing of the nanoparticles content, the foam density is increased. In the other words, foam densities is controlled by the competitive process between the cell nucleation, its growth, and coalescence and reveal that the nucleation process occurred in the well-dispersed modified MNP's in the polymer matrix. In addition, MNP's act as nucleation site to aid the bubble nucleation process during cell formation and enhances the cell densities.

\subsubsection{Thermo-gravimetric analysis (TGA)}

In order to evaluate the role of MNP's on thermal properties of PUF's, TGA experiments were done on nanocomposite samples and data compared with pristine one data. As shown in Figure 6 and Table 3, by incorporation of $\mathrm{Fe}_{3} \mathrm{O}_{4} @ A E A P N P$ 's from 0.5 to $3.0 \%$, the performed thermal stability was observed for $3 \%$ filled sample. This behavior can be interpreted that, MNP's have high specific thermal capacity that caused to heat preservation, acts as a thermal insulator, delay the degradation process and reduces the heat conduction to the PU matrix.

\subsubsection{Magnetic properties analysis (VSM)}

Figure 7, presented the magnetic hysteresis loops of the $\mathrm{Fe}_{3} \mathrm{O}_{4} @$ @AEAP-PU flexible foams nanocomposite with different content of $\mathrm{Fe}_{3} \mathrm{O}_{4} @$ AEAP NP's. From magnetic hysteresis loops, when the content of MNP's varied from 1.5 to $3.0 \%$, the saturation magnetization $\left(\mathrm{M}_{\mathrm{s}}\right)$ is raised from 0.52 to $0.64 \mathrm{emu} / \mathrm{g}$, respectively which indicate nanocomposite reveals super paramagnetic behavior, because no remanence magnetization is observed. Furthermore, magnetic nanocomposite could be magnetized and modulated $v i a$ an external magnetic field.

\subsubsection{Thermo-mechanical analysis (TMA)}

Linear thermal expansion coefficient $(\alpha)$ and glass transition temperature $\left(\mathrm{T}_{\mathrm{q}}\right)$ are two important measurements in the thermal analysis of the polymers and expected by TMA results. In this study, $\alpha$ is calculated according to Equation 3 , where $\mathrm{dL}$ is length changes, $\mathrm{dT}$ is temperature changes and $\mathrm{L}_{0}$ is initial length of the sample. Thermo-mechanical behaviors of the nanocomposite samples are shown in the Figure 8. As shown in Figure 8 and 9, by incorporation of modified MNP's from 1.5 to $3.0 \%$ in PU matrix, the $\mathrm{T}_{\mathrm{g}}$ value was decreased in comparison with pure foam. Additional, reduction of $T_{g}$ in modified MNP's samples affected by some factors, such as low cross link density, restriction of hard phase domain and enhance in chain mobility.

$$
\propto=\frac{d L}{d T \times L_{0}}
$$



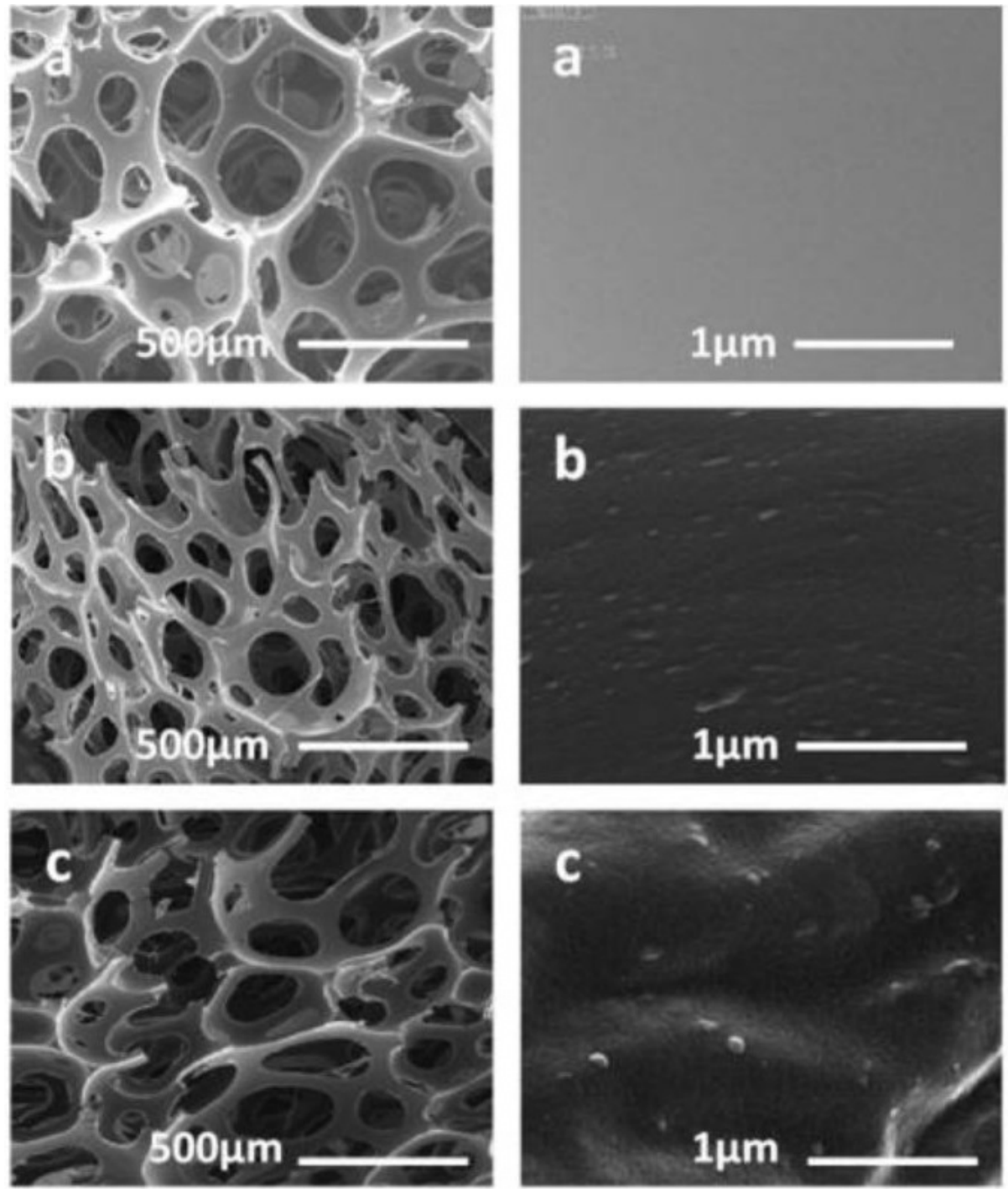

Figure 5. FE-SEM images of PUF foams nanocomposite with different contents of $\mathrm{Fe}_{3} \mathrm{O}_{4} @ A E A P:$ (a) 0.0 ; (b) 1.5 and (c) $3.0 \%$.

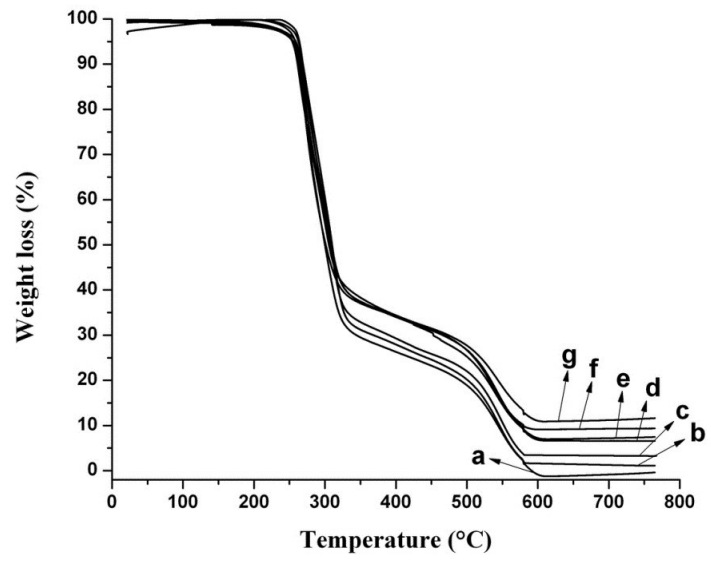

Figure 6. TGA curves of PUF foam nanocomposites with different contents of $\mathrm{Fe}_{3} \mathrm{O}_{4} @$ @AEAP nanoparticles: (a) 0.0; (b) 0.5; (c) 1.0; (d) 1.5 ; (e) 2.0 ; (f) 2.5 and (g) $3.0 \%$.

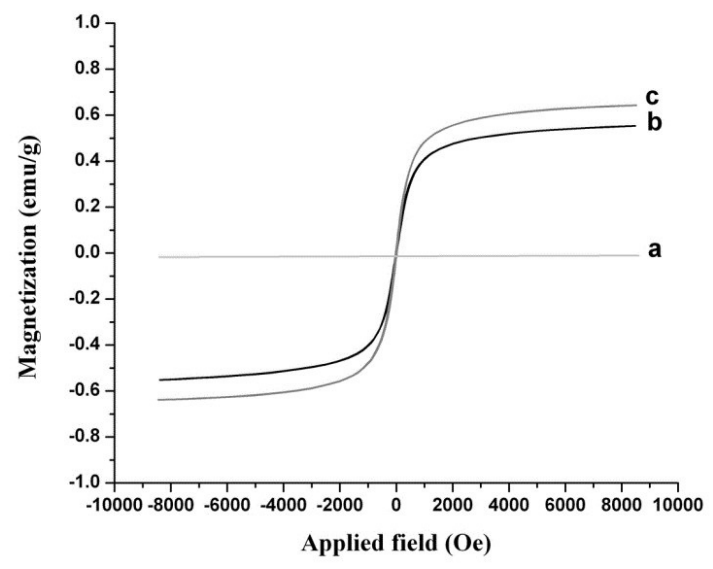

Figure 7. Magnetization hysteresis loops of $\mathrm{Fe}_{3} \mathrm{O}_{4} @$ AEAP-PUF foams with different contenst of $\mathrm{Fe}_{3} \mathrm{O}_{4} @$ AEAP nanoparticles: (a) 0.0 ; (b) 1.5 and (c) $3.0 \%$. 
Table 2. Foam densities of prepared PUF foams.

\begin{tabular}{cccccccc}
\hline Samples (\%) & $\mathbf{a}(\mathbf{0 . 0})$ & $\mathbf{b}(\mathbf{0 . 5})$ & $\mathbf{c ( 1 . 0 )}$ & $\mathbf{d}(\mathbf{1 . 5})$ & $\mathbf{e}(\mathbf{2 . 0})$ & $\mathbf{f}(\mathbf{2 . 5})$ & $\mathbf{g ( 3 . 0 )}$ \\
\hline Density $\left(\mathbf{g} / \mathbf{c m}^{3}\right)$ & 0.027 & 0.038 & 0.042 & 0.047 & 0.052 & 0.055 & 0.058 \\
\hline
\end{tabular}

Table 3. $\mathrm{T}_{5 \%}, \mathrm{~T}_{10^{\circ},}, \mathrm{T}_{\max }$ and ash content $(\%)$.

\begin{tabular}{|c|c|c|c|c|}
\hline $\begin{array}{c}\mathrm{Fe}_{3} \mathrm{O}_{4} @ \text { AEAP } \\
(\%)\end{array}$ & $\begin{array}{l}\mathbf{T}_{5 \%} \\
\left({ }^{\circ} \mathrm{C}\right)\end{array}$ & $\begin{array}{l}\mathrm{T}_{10 \%} \\
\left({ }^{\circ} \mathrm{C}\right)\end{array}$ & $\begin{array}{l}\mathrm{T}_{\max } \\
\left({ }^{\circ} \mathrm{C}\right)\end{array}$ & $\begin{array}{c}\text { Ash content } \\
(\%)\end{array}$ \\
\hline $\mathrm{a}(0.0)$ & 258.01 & 265.54 & 765.02 & 0.14 \\
\hline $\mathrm{b}(0.5)$ & 259.66 & 268.01 & 764.80 & 1.11 \\
\hline $\mathrm{c}(1.0)$ & 262.57 & 268.73 & 767.60 & 3.31 \\
\hline $\mathrm{d}(1.5)$ & 263.12 & 270.05 & 765.25 & 6.59 \\
\hline e (2.0) & 261.93 & 270.90 & 764.88 & 7.46 \\
\hline$f(2.5)$ & 264.36 & 271.27 & 766.76 & 9.35 \\
\hline $\mathrm{g}(3.0)$ & 265.70 & 272.70 & 767.75 & 11.63 \\
\hline
\end{tabular}

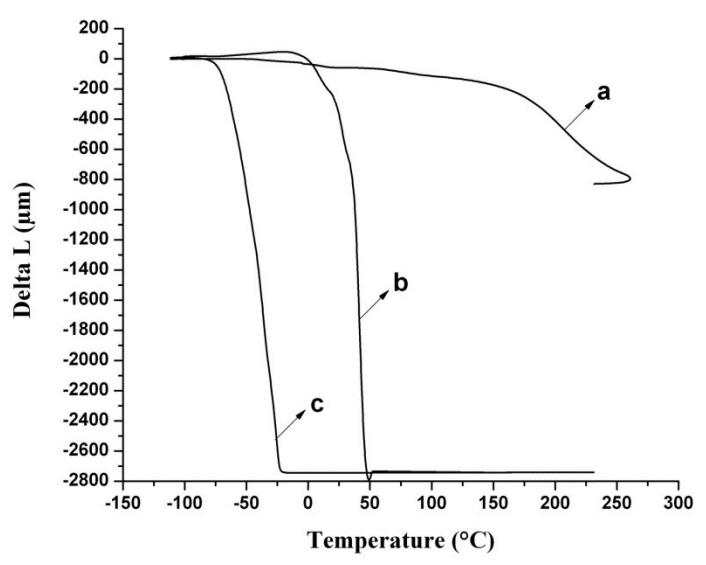

Figure 8. TMA curves of PUF foam nanocomposites with different contents of $\mathrm{Fe}_{3} \mathrm{O}_{4} @$ AEAP: (a) 0.0; (b) 1.5 and (c) 3.0\%.

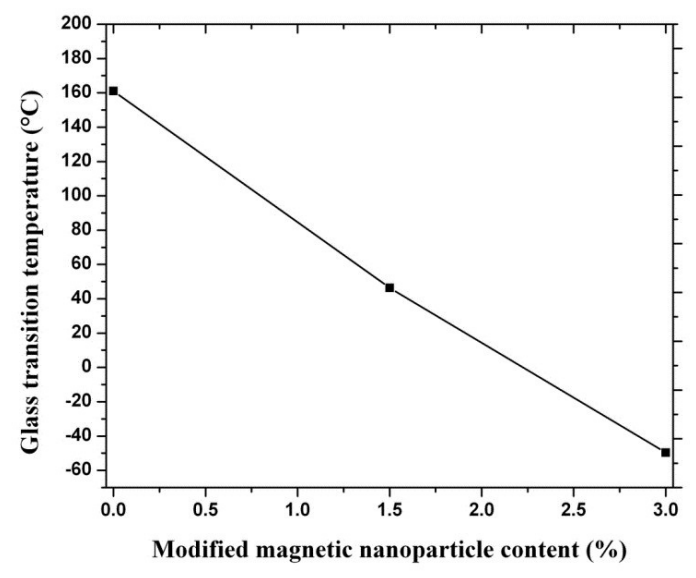

Figure 9. Glass transition temperature $\left(\mathrm{T}_{\mathrm{g}}\right)$ of PUF foam nanocomposite with different percent of MNP's (0.0, 1.5 and 3.0).

\section{Conclusion}

In summary, magnetic polyurethane flexible foam nanocomposites are prepared by incorporation of synthesized $\mathrm{Fe}_{3} \mathrm{O}_{4} @$ AEAP NP's in polymer matrix via in-situ polymerization. The presence of reactive functional groups on MNP's surface improved the interaction between inorganic nanofiller and polymer matrix. The results of the thermo-gravimetric analysis showed thermal stability of MNP's nanocomposite enhanced because of MNP's act as a thermal barrier. TMA results $\mathrm{T}_{\mathrm{g}}$ decrements due to reduction of hard phases domain and limitation of soft segment mobility and freedom. The FE-SEM images showed that the modified MNP's acted as the nucleation sites during cell formulation and led to the cell size decrements as well as cell density increments. Finally VSM results indicated super paramagnetic behavior for nanocomposites.

\section{Acknowledgements}

The authors thank Imam Khomeini International University (IKIU) for the financial supporting of Dr. Alavi Nikje.

\section{References}

1. Nikje, M. M. A., \& Tehrani, Z. M. (2010). Polyurethane rigid foams reinforced by doubly modified nano silica. Journal of Cellular Plastics, 46(2), 159-172. http://dx.doi. org/10.1177/0021955X09350526.

2. Gao, X., Zhu, Y., Zhao, X., Wang, Z., An, D., Ma, Y., Guan, S., Du, Y., \& Zhou, B. (2011). Synthesis and characterization of polyurethane/ $\mathrm{SiO}_{2}$ nanocomposites. Applied Surface Science, 257(10), 4719-4724. http://dx.doi.org/10.1016/j. apsusc.2010.12.138.

3. Shan, C. W., Idris, M. I., \& Ghazali, M. I. (2012). Study of flexible polyurethane foams reinforced with coir fibres and tyre particles. International Journal of Applied Physics and Mathematics, 2(2), 123-130. http://dx.doi.org/10.7763/ IJAPM.2012.V2.67.

4. Cinelli, P., Anguillesi, I., \& Lazzeri, A. (2013). Green synthesis of flexible polyurethane foams from liquefied lignin. European Polymer Journal, 49(6), 1174-1184. http://dx.doi.org/10.1016/j. eurpolymj.2013.04.005.

5. Alavi Nikje, M. M., Farahmand Nejad, M., Shabani, K., \& Haghshenas, M. (2013). Preparation of magnetic polyurethane rigid foam nanocomposites. Colloid \& Polymer Science, 291(4), 903-909. http://dx.doi.org/10.1007/s00396-012-2808-6.

6. Nikje, M. M. A., \& Tehrani, Z. M. (2010). Novel modified nanosilica-based on synthesized dipodal silane and its effects on the physical properties of rigid polyurethane foams. Designed Monomers and Polymers, 13(3), 249-260. http://dx.doi.org/1 $0.1163 / 138577210 X 12634696333631$.

7. Sant'Anna, S. S., Souza, D. A., Carvalho, C. F., \& Yoshida, M. I. (2008). Morphological and thermal analyses of flexible polyurethane foams containing commercial calcium carbonate. Eclética Química, 33(1), 55-60. http://dx.doi.org/10.1590/ S0100-46702008000200008.

8. Liu, T., Mao, L., Liu, F., Jiang, W., He, Z., \& Fang, P. (2011). Preparation, structure, and properties of flexible polyurethane foams filled with fumed silica. Wuhan University Journal of Natural Sciences, 16(1), 29-32. http://dx.doi.org/10.1007/ s11859-011-0706-2.

9. Bahrambeygi, H., Sabetzadeh, N., Rabbi, A., Nasouri, K., Shoushtari, A., \& Babaei, M. (2013). Nanofibers (PU and $\mathrm{PAN}$ ) and nanoparticles (Nanoclay and MWNTs) simultaneous 
effects on polyurethane foam sound absorption. Journal of Polymer Research, 20(2), 1-10. http://dx.doi.org/10.1007/ s10965-012-0072-6.

10. Verdejo, R., Stämpfli, R., Alvarez-Lainez, M., Mourad, S., Rodriguez-Perez, M. A., Brühwiler, P. A., \& Shaffer, M. (2009). Enhanced acoustic damping in flexible polyurethane foams filled with carbon nanotubes. Composites Science and Technology, 69(10), 1564-1569. http://dx.doi.org/10.1016/j. compscitech.2008.07.003.

11. Gao, X., Guo, Y., Tian, Y., Li, S., Zhou, S., \& Wang, Z. (2011). Synthesis and characterization of polyurethane/zinc borate nanocomposites. Colloids and Surfaces. A, Physicochemical and Engineering Aspects, 384(1-3), 2-8. http://dx.doi.org/10.1016/j. colsurfa.2010.11.037.

12. Saha, M. C., Kabir, M. E., \& Jeelani, S. (2008). Enhancement in thermal and mechanical properties of polyurethane foam infused with nanoparticles. Materials Science and Engineering A, 479(1-2), 213-222. http://dx.doi.org/10.1016/j.msea.2007.06.060.

13. Zhou, L., Li, G., An, T., \& Li, Y. (2010). Synthesis and characterization of novel magnetic $\mathrm{Fe}_{3} \mathrm{O}_{4}$ /polyurethane foam composite applied to the carrier of immobilized microorganisms for wastewater treatment. Research on Chemical Intermediates, 36(3), 277-288. http://dx.doi.org/10.1007/s11164-010-0134-5.

14. Cao, H., He, J., Deng, L., \& Gao, X. (2009). Fabrication of cyclodextrin-functionalized superparamagnetic $\mathrm{Fe}_{3} \mathrm{O}_{4}$ /aminosilane core-shell nanoparticles via layer-by-layer method. Applied Surface Science, 255(18), 7974-7980. http://dx.doi. org/10.1016/j.apsusc.2009.04.199.

15. Chi Hao, L., Haji Badri, K., \& Haji Ahmad, S. (2011). Mechanichal and thermal properties of palm-based polyurethane composites filled with $\mathrm{Fe}_{3} \mathrm{O}_{4}$, PANI and PANI/ $\mathrm{Fe}_{3} \mathrm{O}_{4}$. Sains Malaysiana, 40(4), 373-378.

16. Morel, A. L., Nikitenko, S. I., Gionnet, K., Wattiaux, A., LaiKee-Him, J., Labrugere, C., Chevalier, B., Deleris, G., Petibois, C., Brisson, A., \& Simonoff, M. (2008). Sonochemical approach to the synthesis of $\mathrm{Fe}_{3} \mathrm{O}_{4} @ \mathrm{SiO}_{2}$ core-shell nanoparticles with tunable properties. ACS Nano, 2(5), 847-856. PMid:19206481. http://dx.doi.org/10.1021/nn800091q.

17. Lu, Y., Yin, Y., Mayers, B. T., \& Xia, Y. (2002). Modifying the surface properties of superparamagnetic iron oxide nanoparticles throuth a sol-gel approach. Nano Letters, 2(3), 183-186. http:// dx.doi.org/10.1021/n1015681q

18. Ramos, J., Millán, A., \& Palacio, F. (2000). Production of magnetic nanoparticles in a polyvinylpyridine matrix. Polymer, 4l(24), 8461-8464. http://dx.doi.org/10.1016/S00323861(00)00272-X.

19. Shen, M., Cai, H., Wang, X., Cao, X., Li, K., Wang, S. H., Guo, R., Zheng, L., Zhang, G., \& Shi, X. (2012). Facile one-pot preparation, surface functionalization, and toxicity assay of APTS-coated iron oxide nanoparticles. Nanotechnology, 23(10), 105601. http://dx.doi.org/10.1088/0957-4484/23/10/105601.

20. Nikje, M. M. A., \& Tehrani, Z. M. (2010). Thermal and mechanical properties of polyurethane rigid foam/modified nanosilica composite. Polymer Engineering and Science, 5(3), 468-473. http://dx.doi.org/10.1002/pen.21559.

21. Feng, B., Hong, R. Y., Wang, L. S., Guo, L., Li, H. Z., Ding, J., Zheng, Y., \& Wei, D. G. (2008). Synthesis of $\mathrm{Fe}_{3} \mathrm{O}_{4} /$ APTES/PEG diacid functionalized magnetic nanoparticles for MR imaging. Colloids and Surfaces. A, Physicochemical and Engineering Aspects, 328(1-3), 52-59. http://dx.doi. org/10.1016/j.colsurfa.2008.06.024.

22. Narine, S., Kong, X., Bouzidi, L., \& Sporns, P. (2007). Physical Properties of Polyurethanes Produced from Polyols from Seed Oils: II. Foams. Journal of the American Oil Chemists 'Society, 84(1), 65-72. http://dx.doi.org/10.1007/s11746-006-1008-2.

23. Jalilian, M., Yeganeh, H., \& Haghighi, M. N. (2008). Synthesis and properties of polyurethane networks derived from new soybean oil-based polyol and a bulky blocked polyisocyanate. Polymer International, 57(12), 1385-1394. http://dx.doi. org/10.1002/pi.2485.

24. Piszczyk, Ł., Strankowski, M., Danowska, M., Haponiuk, J. T., \& Gazda, M. (2012). Preparation and characterization of rigid polyurethane-polyglycerol nanocomposite foams. European Polymer Journal, 48(10), 1726-1733. http://dx.doi. org/10.1016/j.eurpolymj.2012.07.001.

Received: June 19, 2015

Revised: Nov. 06, 2015

Accepted: Mar. 15, 2016 